Columbia Law School

Scholarship Archive

2015

\title{
From Sunshine to a Common Agent: The Evolving Understanding of Transparency in the WTO
}

Petros C. Mavroidis

Columbia Law School, petros.mavroidis@unine.ch

Robert Wolfe

Follow this and additional works at: https://scholarship.law.columbia.edu/faculty_scholarship

Part of the Antitrust and Trade Regulation Commons

\section{Recommended Citation}

Petros C. Mavroidis \& Robert Wolfe, From Sunshine to a Common Agent: The Evolving Understanding of Transparency in the WTO, 21(2) BROWN J. WORLD AFF. 117 (2015).

Available at: https://scholarship.law.columbia.edu/faculty_scholarship/773

This Article is brought to you for free and open access by the Faculty Publications at Scholarship Archive. It has been accepted for inclusion in Faculty Scholarship by an authorized administrator of Scholarship Archive. For more information, please contact scholarshiparchive@law.columbia.edu. 


\section{From Sunshine to a Common Agent: \\ The Evolving Understanding of Transparency in the WTO}

\begin{tabular}{ll}
\hline Petros C. Mavroidis & Robert Wolfe \\
Professor of Law & Professor in Policy Studies \\
Columbia Law School & Queen's University (Ontario) \\
\hline
\end{tabular}

\section{The Real Jewel in the WTO’s Crown}

TRANSPARENCY OBLIGATIONS HAVE UNDERGONE SUBSTANTIAL transformations since the inception of the General Agreement on Tariffs and Trade (GATT) in 1947. From an obligation to publish general laws affecting trade, the system now includes peer review by governments (in the form of monitoring and surveillance) and efforts to inform the public. These accomplishments are remarkable, but much remains to be done. Originally designed for a handful of developed countries, the global trading system now must provide an expanded knowledge base that benefits 160 member states, millions of economic actors, and hundreds of millions of citizens with inadequate resources to acquire information on their own. But that knowledge base remains incomplete.

The role of the World Trade Organization (WTO) is often thought to be twofold-conducting formal rounds of negotiations and resorting to the dispute settlement system-but the third dimension of its work, which can be

Petros C. Mavroidis is Professor of Law at Columbia Law School, New York, currently on leave at the European University Institure in Florence. He has recently acted as chief reporter for the ALI project "Principles of International Trade." His latest publication is Regulation of International Trade (MIT Press, 2015).

Robert Wolfe is Professor of the School of Policy Studies at Queen's University in Kingston, Ontario. His recent publications include "An Anatomy of Accountability at the WTO" in Global Policy, and "First Diagnose, Then Treat: What Ails the Doha Round?” in World Trade Review. He is coeditor of Adapting Canadian Trade and Commerce Policies to New Global Realities (Institute for Research on Public Policy, forthcoming 2015).

Copyright (C) 2015 by the Brown Journal of World Affairs 


\section{Petros C. Mavroidis and Robert Wolfe}

broadly grouped as transparency and accountability mechanisms, may be the most important. Transparency is part of the WTO's DNA, and can be traced at least through the 1947 GATT back to a 1923 treaty on customs cooperation. This essential element of WTO institutional design illuminates trade policy practices to the benefit of both governments and traders. The WTO's twentieth anniversary is an appropriate moment to describe the impressive evolution of its transparency mechanisms, assess the effectiveness of these mechanisms, and reflect on what more must be done if the WTO is to fulfill its potential as the central institution for governing the global trading system.

The first use of sunshine as a metaphor for transparency as a policy tool is attributed to the U.S. jurist Louis Brandeis. In writing about efforts to regulate finance, Brandeis stated, "Publicity is justly commended as a remedy for social and industrial diseases. Sunlight is said to be the best of disinfectants; electric light the most efficient policeman."

The Brandeis view assumes that agents whose actions are subject to public scrutiny will hew more closely to shared understandings of the common good. If not, other agents provided with information can exercise appropriate discipline. In this view of agency, sunlight contributes more to social order than does coercion. Sunlight plays this role in the trading system by reducing information asymmetries. If the goal of trade agreements is to have binding commitments reduce the policy uncertainty that would otherwise afflict trade relations, then the credibility of those commitments matters. Transparency ought to improve the operation of the trading system by allowing all members to verify that national law, policy, and implementation achieve the objective of the agreements.

The drafters of the GATT assumed that publication of trade laws alone was sufficient. Over time, however, participants in the trading system gradually learned that a more active form of publication was needed to draw relevant information to the attention of other governments in the form of notifications through the Secretariat. ${ }^{2}$ By the 1970 s, it was becoming clear that governments needed a forum to discuss such notifications; in 1980, the GATT Council began a biannual review of notifications. ${ }^{3}$ Neither that review nor the notifications themselves, however, provided enough information. The Uruguay Round agreements created a much more elaborate structure of committees, with a working group on how to make the many new notification requirements work.

Creating opportunities to discuss new measures in advance of their implementation can reduce the potential for conflict between states. For example, when a measure is modified to accommodate the interests of partners, economic actors only have time to adjust if the information is available to them. The original 
GATT transparency system assumed that the primary agents were government officials in developed countries and traders with the sophistication to make use of published information. The picture changed dramatically over the years as more and more countries joined the GATT/WTO, expanding membership from the original 23 countries to today's 160 , and the amount of trade-relevant regulation proliferated. Less than 10 years after the creation of the WTO, members had already concluded that further action was needed to make information available to developing countries, the public, and economic actors.

We first examine the evolution of the transparency discipline within the world trading system, before performing a reality check and discussing whether the transparency obligations have been observed. Next, we suggest that trade policy information is a public good, one that will be under-provided to both traders and smaller members without stronger incentives and/or disciplines. We conclude with three proposals for the optimal future evolution of the transparency obligation.

The paper proposes a stronger role for the WTO Secretariat as a common agent for all participants in the trading system by providing more and more focused sunshine on global trade.

\section{Three Generations of Transparency}

WTO transparency has evolved through three generations. ${ }^{4}$ The first generation refers to the original GATT policies on information from 1947 as elaborated over the years. The second generation refers to the monitoring and surveillance mechanisms, introduced with the conclusion of the Tokyo Round negotiations in 1979 and enhanced in the Uruguay Round negotiations, that led to the creation of the WTO in 1995 . The third generation refers both to managing an enlarged WTO with 160 members and to greater openness to the public, facilitated by the emergence of the Internet, especially after a 2002 decision on access to documents.

\section{First-GenERATION TeETHING PROBLEMS}

Most first-generation WTO transparency provisions relate to the obligations incumbent on governments for trade policy transparency at home. This principle is first seen in Article X of the GATT on "Publication and Administration of Trade Regulations," but it is now found in many other WTO agreements. Publication, which remains essential, proved to have at least two limitations. 


\section{Petros C. Mavroidis and Robert Wolfe}

First, publication is restricted to "laws of general application"-a sensible decision, since otherwise a cost would be imposed on WTO members to provide information that might be of little use to traders. ${ }^{5}$ Disputes have arisen, and continue to arise, about what "general application" means, which is one of the

WTO members have consistently preferred to be parsimonious about what they publish, since some of the information provided could be self-incriminating. reasons why close to 10 percent of all WTO disputes concern GATT Article X. Such complaints often concern inconsistent administration of domestic customs procedures, including, for example, a complaint by the United States in EC-Selected Customs Matters (DS315). WTO members have consistently preferred to be parsimonious about what they publish, since some of the information provided could be self-incriminating.

Second, though the obligation emphasizes unveiling information in a publicly available form, procurement of that information can nonetheless be costly. Most traders are helped, for example, by information about subsidies published in a local newspaper that is not in a official WTO language. Publication at home does not necessarily mean that other members of the WTO are notified. The only significant GATT notification requirements are in Article XVI, which requires notification of subsidies, and Article XXIV, which requires notification regarding free trade agreements (FTAs). ${ }^{6}$

\section{FRom Publication to Notification}

Notification obligations began to expand in the 1980s as the new Tokyo Round obligations took the GATT "behind the border," by creating new obligations pertaining to measures applied to both domestic as well as imported products that had been cleared through customs. Until then, the focus had been on measures at the border that hit only imports, but the remarkable reduction of the level of tariffs allowed traders to better understand the bite of domestic policies and persuaded them that it was high time they were rationalized. This type of discipline further expanded with the advent of the WTO in 1995. Publication at home is barely enough when most trade measures have their effects at the border. To encourage submission of information, members agreed in one of the decisions adopted with the creation of the WTO that notification was without prejudice to whether a measure was consistent with the member's WTO obligations. ${ }^{7}$ They established a Central Registry of Notifications to 
receive and maintain notifications, to inform each member annually of its regular notification obligations, and to draw the attention of individual members to regular notification requirements that remain unfulfilled. By 2011, the central database covered 176 notification requirements, of which 42 were recurring requirements on a semiannual, annual, biennial, or triennial basis. ${ }^{8}$ This number has increased with the new Trade Facilitation Agreement.

Notification is one leg of second-generation obligations, the other being the establishment of monitoring and surveillance mechanisms. Members review each other's implementation of the agreements in the various WTO committees, often with an opportunity to ask each other questions about their respective notifications. The Agriculture Committee, for example, devotes a significant part of each regular meeting to reviewing notifications that range from information regarding the level of export subsidies paid to the adoption of policies concerning environmental protection. ' The Committee on Regional Trade Agreements' (CRTA) Transparency Mechanism allows discussion of notification of new regional trade agreements (RTAs) to expose the potentially negative aspects of an RTA without requiring members to give it formal approval. ${ }^{10}$ Peer review of the ensemble of a country's trade policy, but not consideration of specific obligations, is also found in the Trade Policy Review Mechanism (TPRM). Discussion there is based on major reports written both by the WTO Secretariat and the member under review. ${ }^{11}$

The most elaborate monitoring and surveillance mechanism is now known as the specific trade concerns (STC) procedure in the Sanitary and Phyto-sanitary Measures and Technical Barriers to Trade committees. WTO members can informally challenge the consistency of notified measures by raising an STC; if the member is not satisfied with the responses given, it can raise a formal dispute by requesting consultations in the dispute settlement system with the member that had adopted the challenged measure. ${ }^{12}$ The term is not mentioned in the text of any WTO agreement, although many agreements encourage a process in which members may engage in ad hoc consultations on their notification of new trade measures, and others, notably the Agriculture Committee, also now have an online database of matters raised in the committee.

\section{INTO THE GREAT WIDE OPEN}

Third-generation transparency focuses on the efficiency of procuring information. The Technical Barriers to Trade (TBT) Agreement is the front-runner here. It requires the establishment of inquiry points, where private traders can seek 


\section{Petros C. Mavroidis and Robert Wolfe}

information from a foreign government about the workings of technical regulations. Traders therefore do not have to depend on their own government for this information, and other governments, too, will receive similar information in the TBT Committee. Inquiry points are the first step toward creating a socalled "single window" for trading information in each member state, thus reducing the search costs of information procurement. In a similar vein, the WTO's new Integrated Trade Intelligence Portal (I-TIP) provides a single entry point for information compiled by the WTO on trade policy measures. I-TIP covers both tariff and non-tariff measures affecting trade in goods as well as information on trade in services, trade in government procurement markets, regional trade agreements, and the accession commitments of WTO members. This transparency system looks good on paper, but does it work?

\section{Reality Check}

The evolution of the GATT/WTO transparency system through three generations of increasing complexity and sophistication has created a window into the trading system, but that window is often clouded. The Central Registry system with its detailed annual reports is both essential and frustrating because only experts can make sense of the data. More valuable is the section of the periodic Trade Policy Review (TPR) reports on each country that details their notification performance. ${ }^{13}$ But this kind of naming and shaming, which also takes place in some committees, has not led to a large increase in notifications.

We see four potential reasons why governments do not improve notification. The first is bureaucratic incapacity, which is the case for many developing countries whose trade ministries lack data or knowledge, for example about a subsidy granted by another ministry. Second, member states might worry about opening themselves to criticism in a dispute-perhaps about a measure that

\section{Many officials report a lack of trust} they suspect is illegal, or about a notification that might require between trade negotiators and other showing one's cards in a negotiagovernment agencies in state capitals. tion. Third, many officials report a lack of trust between trade negotiators and other government agencies in state capitals, which is said to be more significant than any lack of trust in Geneva; officials responsible for a regulation affecting public health may see no need to explain themselves to the trade negotiators. This lack of trust inhibits the ability of trade officials to gather information for notification of domestic policies, which are the policies where 
notification is most valuable. Fourth, there is ambiguity about what exactly to notify. Case law, as cited above, has interpreted "law of general application" as tantamount to measures that are not transaction-specific. This interpretation might be enough when we deal with the imposition of duties on one particular shipment (that would not be characterized as a law of general application) but insufficient on other occasions;

In practice then, the only discipline exacted toward those who violate transparency obligations is, in fact, transparency. We argue that more is needed. for example, when an antidumping duty is imposed, since similar duties might or might not cover specific transactions. Similar ambiguities concern the understanding of the term "subsidy," since it is often difficult to understand whether a benefit, for example, has been bestowed. The antisubsidy counterfactual is often difficult to establish.

In the latest in a long series of such efforts, the chairperson of the General Council wrote to the chairs of all WTO bodies in February 2009 asking them to consult with members on ways to improve the timeliness and completeness of notifications and other information flows on trade measures. The subsequent annual overview of the trading system by the Director-General contained a new section on transparency, repeated every year year. ${ }^{14}$ This section revealed that many of the required notifications are late, incomplete, or never submitted at all. No committee has a perfect record, although some are better than others. The record of notification of industrial subsidies is especially poor. ${ }^{15}$ While many of the poor performers are small countries of little overall significance in the trading system, some of the recalcitrant are among the largest traders. In April 2013, the chair of the Subsidies and Countervailing Measures (SCM) Committee listed the 71 members that had not made 2011 notifications, which included four of the top 30 merchandise exporters: China, Indonesia, Thailand, and the United Arab Emirates. ${ }^{16}$ The excuses offered included technical and capacity constraints as well as coordination difficulties.

A related problem is the inability or unwillingness of many members to use second-generation transparency mechanisms by asking questions in committees. The nearly 900 questions asked in the SCM committee from 2008 to 2012 were asked by only 16 members, all but two of whom are G-20 countries, although the questions were posed to 58 members (counting the $\mathrm{EU}$ as one in both cases). This reticence may be a manifestation of the glass house syndrome: some members might be afraid to ask a question, since doing so might provoke questions about their own behavior. Alternatively, members might not ask ques- 


\section{Petros C. Mavroidis and Robert Wolfe}

tions because they do not see the value of either notification or surveillance.

Violations of transparency obligations are, like any other form of noncompliance, justiciable. Under the de facto system of prospective remedies adopted by WTO panels, members that have failed in their obligation to disclose information need only notify the WTO ex post facto. An illustrative case is the Trondheim litigation, in which Norway had failed to respect its transparency obligations under the Government Procurement Agreement. ${ }^{17}$ The United States, after discovering Norway's failure to comply with transparency obligations, prevailed in the subsequent GATT dispute but had to be content with a Pyrrhic victory. All that the panel requested from Norway was a promise never to repeat this behavior. In practice then, the only discipline exacted toward those who violate transparency obligations is, in fact, transparency. We argue that more is needed.

\section{EMPOWERMENT OF THE COMMON Agent}

The objective of WTO transparency is not only to reduce information asymmetries among governments, but also those among the state, economic actors, and citizens. Article X.1 of the GATT requires publication of certain trade policy information for the benefit of both governments and traders. Article X.3 requires the creation of independent administrative law tribunals to allow prompt adjudication of customs matters. More recent WTO agreements go further in specifying domestic administrative law requirements. While the WTO is primarily thought of as a contract among governments, its rules are also meant to serve traders. The rights of private parties under the Government Procurement Agreement and the obligation to establish inquiry points under the TBT Agreement and Agreement on the Application of Sanitary and Phytosanitary Measures (SPS) go in the same direction; these are obligations aiming to benefit private agents directly, rather than WTO members. The WTO's differing objectives create a trilemma: the surveillance system is designed to monitor official obligations on behalf of governments. Citizens and analysts, however, are more interested in the economic or social impact of policy, not the implementation of commitments. Traders are only served if governments publish information at home and if all WTO data is accessible in user-friendly form. In short, everyone needs more information, and they need efficient access to it, but their needs are not being met by the current system. Trade policy information is a public good, especially for traders and for smaller member states. Like all public goods, this information tends to be underprovided. We first explore the missing incentives in the system before proposing a solution. 
WHOSE AGENCY?

It is by now commonplace to treat information as a commodity. There are undeniable search costs when trying to unearth information, and some agents cannot bear them. Developing countries in the WTO-which are typically poor-profit considerably from transparency, since procuring information is more costly for them. They export small numbers of goods and services to few Trade policy information is a public good, especially for traders and for smaller member states. Like all public goods, this information tends to underprovided. countries, and they lack a large diplomatic network of officials gathering commercial information abroad. Similarly, smaller traders lack in-house trade intelligence capacity and cannot afford to procure it from big multinational law firms.

When it comes to honoring their transparency obligations, WTO members seem to more often than not emphasize their right to divulge or not divulge, focusing less on the consequence of this exercise of discretion-which is that others may be limited in their right to know about measures affecting trade. Moreover, one should not underestimate the collective action problem that arises, even for large members. For instance, why should the United States incur the cost of procuring information through reverse notifications when all members will benefit from the information revealed? The United States has submitted extensive reverse notifications of Chinese and Indian subsidies, but few other members have the capacity to generate such analysis of another member's policies. The United States might also have an incentive in similar situations to keep information to itself rather than serving the general good with a reverse notification or a detailed question in a committee.

Given the missing incentives to notify, one solution might be to cut through the trilemma by enabling a disinterested party to acquire and disseminate information as the common agent of all participants in the trading system.

\section{WHAT HAPPENS ALREADY}

Our analysis shows that small countries and small firms in particular need more support from the WTO in terms of supplying transparency regarding their own policies. The Secretariat has some capacity to act as the common agent of the members; this role should be enhanced. The WTO has multiple principals_-160 


\section{Petros C. Mavroidis and Robert Wolfe}

member governments, but also citizens and hundreds of millions of traders. Sunshine as now practiced does not properly enable these agents to discipline other agents who may not be playing by the rules. In order to ensure such discipline is possible, two things are required, both of which can only come from a common agent: active efforts to 1 ) increase the amount of information available; and 2) make that information widely available in a useful way. The move toward increasing the role of the WTO Secretariat is the implicit response to the failure of WTO members to submit notifications.

The core of each TPR report is based on the notifications from members, but each report builds on a far wider range of information. The Secretariat collects data from official sources, which include questionnaires to members under review, and non-official sources, including other international organizations, media reports, and NGOs. To ensure accuracy, the Secretariat seeks to verify data that comes from non-official sources when discussing the draft of its report with the members. ${ }^{18}$

Members created a new mechanism in response to the Great Recession that began in 2008. After the G-20 asked the WTO and other international organizations to monitor their collective commitment to avoid protectionism, the WTO began issuing periodic crisis-monitoring reports. These reports are a novel extension of the mandate of the Trade Policy Review Body, that is, the WTO organ administering the functioning of TPRM. ${ }^{19}$ The Director-General claimed that he had the authority under the WTO agreements to conduct the crisis monitoring, but members only formalized this role in December 2011. ${ }^{20}$ Members had discovered that the periodic Secretariat reports were factual and useful, especially for smaller members that could not begin to generate such data on their own, and that the Secretariat was not trying to add to the dispute settlement system through the back door. ${ }^{21}$

The Secretariat can only do so much, however. It too faces search costs and has limited power of naming and shaming.

\section{A LOOK INTO THE FUTURE}

Transparency cannot have the same content for WTO members as for individual traders. Irrespective of whether we talk about customs matters, technical barriers to trade, or government procurement, the intensity of information should be different. Traders do not possess sophisticated bureaucracies that will process supplied information for them. One would not expect that small and medium enterprises would have in-house lawyers, for example, who will 
process information regarding measures in export markets in a systematic manner in order to assess their consistency. The potential usefulness of similar investment for traders would by far outweigh its costs for the WTO. The level of disaggregation should be different when information is meant to accustom traders to trade policies. We see a role for the WTO as the common agent to supply information when it is undersupplied. In effect, the Secretariat can function as a complement in Geneva to the development of the single window for certain kinds of information in capitals. We would like to see three innovations that would support the changing role that the WTO ought to play in international trade relations.

First, the Secretariat should be more proactive in collecting information and making it available, which would require some internal reorganization of the staff and most likely some additional investment as well. The inadequate notifications by WTO members can be partially mitigated by giving the Secretariat increased scope and resources to act as the common agent of members. In this role, the Secretariat would assemble information that ought to have been disseminated through notifications. This authority should be subject to the principle that any information collected in this way should be verified by members.

Second, the Secretariat should keep a data set with the number of notifications in general and by agreement for each WTO member for a five-year period. If in any year a given WTO member is below the mean, either for the membership as a whole or for members at a similar stage of development, then WTO officials would target that member on a priority basis. Similarly, if important developments occur and there is no upward deviation from the mean number of notifications, then again this WTO member should be reviewed on a priority basis.

Third, as the common agent, the Secretariat needs to pay special attention to collecting ongoing information about the operation of regional or preferential trade agreements (PTAs). The WTO is not the only game in town, as over 500 regional trade schemes have been established and some mega-regional schemes are in the works. We know little, if anything, about the workings of those schemes after their review by the CRTA has been completed. Yet, these agreements are full of TBT+, SPS+, and GPA+ disciplines, which at least potentially affect each and every WTO member and trader. ${ }^{22} \mathrm{~A}$ bridge must be built to ensure a steady flow of information about the operation of PTAs. Such exercise of transparency and dissemination matters for PTA participants themselves because most such agreements have weak institutional structures, no strong notification obligations, and no Secretariat to process notifications in any case. 


\section{Petros C. Mavroidis and Robert Wolfe}

\section{Sunshine Requires a STRONGer LenS}

Justice Brandeis might have overstated the efficiency of sunshine, but he certainly did not overstate the case for transparency. The work of Nobel Prize-winning economists, such as George Akerlof, Joseph Stiglitz, Michael Spence, and Oliver E. Williamson, demonstrates that information should be treated like all other scarce commodities. Information, after all, is costly and not equally accessible. Transparency obligations aim to equalize conditions of procuring information across all trading nations and their traders, assuming fair play by all. In the case of international trade, where almost all government intervention affects the trade outcome in one way or the other, the quest for equalizing access to information is also a quest for efficient access to information. It does not help traders much to say that information is available if they do not also know where it is available. We see a need to strengthen the existing disciplinary measures and to expand the role for the WTO to act as a lens-by helping to shine a more focused light where it is needed. Many more actors will then be able to obtain the information necessary for disciplining the few who try to restrict trade at the expense of the many. It is high time that the WTO addresses the oft-forgotten inconvenient truth: the WTO is a government-to-government contract that affects the lives of individual traders. In this vein, we recommend a more active role for the WTO Secretariat and a wider use of the information provided.

As more developing countries participate in global value chains and as micro-firms in all countries participate in rapidly expanding Internet-enabled trade, a much wider group of economic actors will figure prominently in global trade. The issue of information asymmetry will therefore become exponentially more complex. No PTA can create the apparatus necessary to solve this problem. The WTO can provide such information, but only with an expanded role for the Secretariat as a common agent to collect, aggregate, and disseminate trade policy intelligence. $\mathbb{1}$

\section{NoTES}

1. Louis D. Brandeis, Other People's Money and How the Bankers Use It (New York: F.A. Stokes, 1914).

2. "Notifications Required from the Contracting Parties: Note by the Secretariat," General Agreement on Tariffs and Trade, August 1, 1978.

3. WTO Working Group on Notification Obligations and Procedures, "Background Note by the Secretariat on Notification Procedures in the GATT since 1979," (Geneva: World Trade Organization, June 30,1995$)$.

4. This section is based in part on Terry Collins-Williams and Robert Wolfe, "Transparency as a Trade Policy Tool: The WTO's Cloudy Windows," World Trade Review 9, no. 4 (October 2010): 551-81; Robert Wolfe, "Letting the Sun Shine in at the WTO: How Transparency Brings the Trading System to Life," 


\section{From Sunshine to a Common Agent}

(World Trade Organization Staff Working Paper, March 2013). For a superb history of notifications in the WTO, see: M. Bacchetta, J. Richtering, and R. Santana, "How Much Light Do WTO Notifications Shed on NTMs?," in Non-Tariff Measures: A Fresh Look at Trade Policy's New Frontier, ed. O. Cador and M. Malouche (Washington, DC: World Bank and Centre for Economic Policy Research, 2012), 19-50.

5. As per consistent case law, the term "laws of general application" covers measures that are not transaction-specific. See, for example, the lengthy analysis in the Appellate Body report on EC-Selected Customs Matters at www.wto.org/disputes.

6. "Notifications Required from the Contracting Parties," General Agreement on Tariffs and Trade.

7. "Ministerial Decision on Notification Procedures, Adopted by the General Council," World Trade Organization, January 31, 1995.

8. World Trade Organization, Overview of Developments in the International Trading Environment: Annual Report by the Director-General (Geneva: World Trade Organization, November 21, 2011).

9. At the March 2015 meeting, for example, members questioned Costa Rica about its domestic support (subsidies) for rice. See: "Debate on members' paper on agricultural domestic support reveals diverging views," World Trade Organization, March 4, 2015.

10. Petros C. Mavroidis, "Always Look at the Bright Side of Non-Delivery: WTO and Preferential Trade Agreements, Yesterday and Today," World Trade Review 10 (2011): 375-87.

11. World Trade Organization, Overview of Developments, 2011.

12. Henrik Horn, Petros C. Mavroidis, and Erik N. Wijkstrom, "In the Shadow of the DSU: Addressing Specific Trade Concerns in the WTO SPS and TBT Committees," Journal of World Trade 47 (2013): 729-60.

13. TPR reports are the reports prepared by the WTO Secretariat in the context of the Trade Policy Review Mechanism that comprehensively explain the trade policies of WTO members.

14. World Trade Organization, Overview of Developments in the International Trading Environment: Annual Report by the Director-General (Geneva: World Trade Organization, November 18, 2009).

15. Collins-Williams and Wolfe, "Transparency as a Trade Policy Tool"

16. "Notification Requirements under the Agreement on Subsidies and Countervailing Measures: Background Note by the Secretariat," World Trade Organization, Committee on Subsidies and Countervailing Measures, June 10, 2013; "Minutes of the Regular Meeting Held on April 22, 2013," World Trade Organization, August 5, 2013.

17. Petros C. Mavroidis, "Government Procurement Agreement; the Trondheim Case: the Remedies Issue," Aussenwirtschaft 48 (1993): 77-94.

18. World Trade Organization, Overview of Developments, 2011, para. 180.

19. World Trade Organization, Report to the TPRB from the Director-General on Trade-Related Developments (Mid-October 2011 to Mid-May 2012) (Geneva: World Trade Organization, Trade Policy Review Body, June 28, 2012).

20. "Trade Policy Review Mechanism: Decision of December 17, 2011," World Trade Organization, December 19, 2011.

21. Robert Wolfe, "Protectionism and Multilateral Accountability During the Great Recession: Drawing Inferences from Dogs Not Barking," Journal of World Trade 46 (August 2012): 777-814.

22. By this we mean that PTA partners agree to strengthened TBT, SPS, and GPA commitments. They thus agree to include obligations that are not included in the current TBT-, SPS-, and GPA Agreements. 